Massey University, New Zealand

\title{
Thom Conroy
}

\section{Only a god can save us}

\section{Biographical note:}

Thom Conroy is a Senior Lecturer in Creative Writing and a fiction writer whose work has appeared in various journals in the US and New Zealand, including Landfall, Sport, New England Review, Alaska Quarterly Review, and Kenyon Review. His fiction has been recognised by Best American Short Stories 2012 and has won various other awards, including the Katherine Ann Porter Prize in Fiction. He is currently completing The Naturalist, a historical novel featuring the nineteenth-century explorer, rebel, and naturalist Ernst Dieffenbach.

Keywords:

Creative writing - New Zealand 
Isobel had been looking forward to the companionship of Todd Connor on this journey because of his passion for Heidegger. He had been a student of hers in her first days at university when she was in her mid-twenties. What she thought of when she remembered those days was a bright and rich emptiness. Todd had young children at the time, and he and his wife Emily had lived in an old farmhouse filled with the presence of farm workers and guests. She had visited this house once, decades ago now, and what she recalled were the embers in a white hearth and their shadows playing among the bare feet of strangers. But Todd had sprained his ankle - a fall from a tractor, of all things - and so his wife Emily was sitting beside Isobel this morning as they flew over the Bohemian Forest, which spread green-grey like a dark mould through the valleys below them.

What brought them to Bohemia was a miracle. In his famous Der Speigel interview, the philosopher Martin Heidegger had said, as an aside on his overview of modern life, "Only a God can save us". It had become the title of the article when it was published after Heidegger's death. Nur noch ein Gott kann uns retten. Now, it seemed, the God had descended. Isobel was a Heideggerian scholar, but she resisted the hype, and this is why she had come out here to see for herself. In fact, had it been anyone other than Dr Grundel who contacted her, she would have dismissed the reports out of hand. She had read them, of course - how could she have missed a news story in which, for once, philosophy was the main event?

The World has Worlded. Heidegger's Dream Realised. New Bohemian Harmony? These stories had come in the spring, and the story had faded quickly enough as summer progressed. For all its wonder, in fact, there was hardly any story at all ... Only this: in a certain hut in a valley in the Bohemian forest Heidegger's fourfold of sky, earth, mortals, and divinities had arrived. Now this sort of thing happened every day, but it was by its very nature ephemeral, a transitory state, the passing shadow of the sun as it closed upon a hillside. Not in this case. In this case, the fourfold opening had emerged and held steady - the world, in other words, had worlded.

A farmer broke the story. Without knowing exactly what it was he had seen, he had rushed into a village - Smi, if Isobel recollected - and said he experienced something indescribable: a sort of gleaming serenity, an equilibrium among the outbuildings of his property and the fields. He travelled to the regional capital and was interviewed by an academic. It was this man's report which first made it to the newspaper. Farmer Finds Nirvana. What was most astonishing was that everyone who visited the place understood. Reporters, politicians, artists - they all agreed that the world had come into unity with itself at this very place. The fourfold of sky, earth, mortal, and divinities had come into alignment and being, as Being, emerged. What was more amazing still was that the photographs revealed the miracle: there was a certain cerulean hue to any picture taken in the vicinity, a shimmering of clarity. The world, everyone agreed, had worlded.

Dr Grungen visited the spot and confirmed everything, but he had taken ill during his visit and there was little to pass onto Isobel in terms of specifics, he explained when they met him at the regional airport. Isobel had last seen the man many years ago, and in the intervening time he had aged terribly, so that he now looked like an obese frog. 
Riding with him in the car to the forest, she could not help stealing glances at the wreckage of his face. In a toilet on a small reserve just outside the forest boundary, she and Emily agreed that the man was repulsive. Isobel wanted to stay professional, but somehow the appearance of the man cast everything into doubt. As they drove deeper into the forest, she recalled the brief email from him, the low-resolution photograph of a patch of brilliant sky seen across the threshold of the hut, and his sparse notes, taken on the site: "There can be no doubt. At last, we are saved ... but why? Language is useless".

Around noon, Grungen turned onto a narrow metal road and they started climbing into the mountains. Now and again, they would see the smoke from a chimney across the valley or catch sight of a dirty goat chained to a tree, but there were no other signs of human habitation. What was worse was that as they drove, the sky began to darken above them - great sails of cloud gathered above the wooded silhouette of the ridges. As the day wore on, Grungen had gone from gregarious to silent, only now and again emitting a grunt as he rounded a sharp corner or, perhaps, sighing when the pale green of a meadow opened in front of them.

Just before nightfall the rain fell. It spilled across the mountains and poured down the ruts of the road so that the car swerved and seemed to be floating. Emily, a strong woman used to farm equipment and hard labour, volunteered to drive. Without speaking, Grungen parked on a muddy shoulder at the edge of a precipice and shifted to the backseat. With Emily behind the wheel, the mood in the car altered, and the three of them began to speak of Heidegger and of the miracle. All three of them were learned and sophisticated people, and yet you could not miss the anticipation in their voices, the urgency that came from their hope of some secular salvation. Atheists, thinkers, folk of a scientific bent, what they longed for was to find this place, and, above all else, to believe.

That night they stayed in a room Grungen had arranged. A small lean-to built onto the back of farmer's house and smelling of hay. Grungen lie down on the floor and immediately fell into a noisy sleep, while Emily and Isobel shared the single bed, their backs and legs touching down the length of their bodies. Isobel waited for Emily to sleep before she returned again to thinking of the woman's husband, Todd. She thought of the letters she and Todd had written back in the last days when people still wrote letters. She thought of one in particular in which Todd had written to her of coming into the presence of Being - both he and Emily spoke in this fashion without the least self-consciousness, even though Iosbel herself, a woman who had dedicated her life to Heidegger, still found it hard to use such terms in conversation.

What Todd had written was that he had been working some piece of land out by a creek somewhere and he fallen asleep beside it. When he woke a few hours later, everything seemed unfamiliar. "Confounding" had been the word in his letter, and she could still see it written squarely and crisply in his hand. His sense of direction was muddled, and the field where he woke struck him as foreign, its colours off, its sense of being strangely heightened. I wandered amid pink scrub with the sound of the water loud in my ears, and knew not where I was. The thought of that line, and of the 
script of Todd's hand opened in Isobel's body, spread like the warmth from the touch of a hand.

In the morning, the storm intensified and Grungen was in no hurry to get up and dressed, in spite of their schedule and the arrangements they had made. They ate a breakfast of tepid porridge in the half-light of the morning, the sound of the rain falling flat on the metal roof above the small, cold kitchen. Then they set off again. The spot to which they were headed was on the German side of the mountains - at least Grungen thought it was - and just over a crest, they came to a checkpoint. A concrete hut sat beside the road with a black and yellow barrier arm raised against the grey of the sky. Grungen started to slow down, but as they were coming close to the checkpoint he gunned the engine and drove through without stopping.

"Why did you do that?" Emily said. "What's the matter with you?"

Grungen smiled, but he did not answer. He just keep up a dangerous speed, taking the gravel turns too fast and gripping the wheel like a madman until they reached a long stone bridge that passed high above a ravine. At the middle of the bridge, he came to a sudden stop and took his place in the backseat again. From there, he said, "It isn't much further, I think. Down into the village and from there we'll get directions".

The village turned out to be a cluster of small, brick buildings. One had a sign atop it with something written in faded Czech letters, but they couldn't read it properly. Emily and Isobel knocked on the door of this building, and a woman opened it, invited them into what seemed to be a kind of postal facility, at least that was the impression Isobel had. The woman knew of the place they spoke. She wrote down some directions in German, but then crossed them out and told them merely to turn left after they passed the large farm.

Isobel was driving now, and she found the farm easily enough, but none of it looked familiar to Grungen. He even had the idea that the woman back in the village had been making a fool of them. Hearing that, Isobel recalled the directions she had scribbled out, and she suggested they follow these instead. These directions took them back out to the main road and from there onto a small, private-looking lane that snaked alongside a partially-concealed creek.

"This looks like it", Grungen said.

They followed this road past a mill and a small group of abandoned houses. As they drove, the storm passed, and now and again an eye of blue opened above some spot in the landscape.

They could not find the place where the fourfold opening had taken place. They drove all that day, following the gravel road until it ended at a woodpile on the side of hill. All of them were disappointed, even Grungen seemed heartbroken. The next day Isobel and Emily would have to catch a flight to Munich, and it was clear they would never reach the place they had come so far to see. The site of the fourfold miracle.

An hour before nightfall, the sun emerged fully, and in its new light they travelled down the main road, slowing now and again to see if some opening summoned them, or, I suppose, in the hope that some sign would appear before it was too late. There 
was nothing like that, of course, and in the twilight Isobel pulled the car over beside a ramshackle barn for them to eat. They had small packages of cold chicken and a bottle of wine, and they took these into the barn where there were dry places to sit. There they ate in silence, sitting in a semi-circle with the timbers of the barn above their heads and the slanted opening of its great doors before them. It was a simple meal they ate, their heads bowed there in that darkness while outside the broad beams of the sun met the walls of the barn and lit the stones of the road so that they shone like water. 